\title{
Análise do desenvolvimento de competências gerenciais na construção civil através do modelo da Aprendizagem Baseada em Problemas adaptado ao contexto organizacional
}

\author{
Analysis of the development of managerial competences \\ in the construction industry using Problem-Based Learning \\ model adapted to the organizational context
}

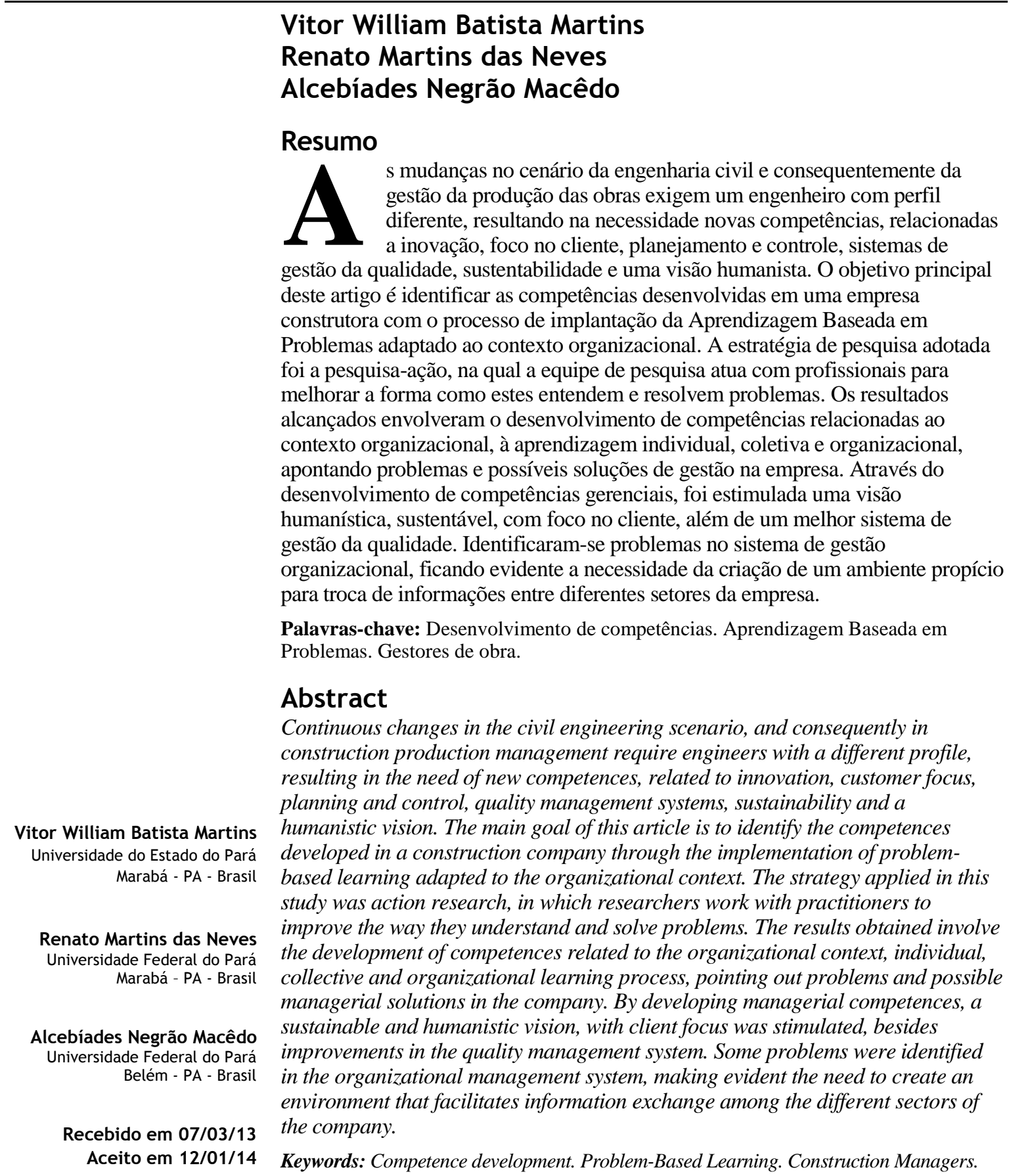




\section{Introdução}

A crescente e constante mudança da competitividade no ramo da construção civil, a velocidade com que novas tecnologias vêm sendo disponibilizadas, a quantidade e o acesso rápido à informação caracterizam um ambiente turbulento, que requer uma grande capacidade de adaptação e aprendizagem nas organizações, o que resulta em uma alteração constante no perfil dos engenheiros civis gestores de obra.

De acordo com Leripio e Cristo (2012), a função do engenheiro ao longo do tempo sofreu considerável evolução, exigindo competências cada vez mais apuradas de tais profissionais. É necessário ter uma visão sistêmica, pensar na obra como um todo, desde aspectos operacionais e econômicos até ambientais. O papel do engenheiro deverá mudar de uma postura passiva de simples executor para uma ativa de inovador, comunicador, educador, tomador de decisões, um fazedor de políticas, engajado nas mudanças que deverão ocorrer nas próximas décadas. Esse cenário obrigará cada vez mais o engenheiro civil, da maneira mais rápida possível, a seguir um dos princípios da qualidade, que é produzir mais (aumento da produtividade) com menos (modo econômico) e melhor utilizando os recursos (sem desperdícios).

As mudanças ocorridas no contexto da engenharia civil e especificamente na gestão de produção das obras exigem um engenheiro com perfil diferente do "tocador de obras". Diante dessa realidade, algumas mudanças ocorreram e irão ocorrer de forma mais rápida, provocando alterações significativas nesse novo perfil profissional dos engenheiros. Essa nova conjuntura exige características mais apuradas de tais profissionais, tornando indispensável o domínio sobre inovação, foco no cliente, planejamento, conhecimento de sistemas de gestão da qualidade, sustentabilidade e uma visão humanista.

Aliados à transformação da sociedade, a globalização e o desenvolvimento tecnológico fazem com que o grande diferencial competitivo das organizações passe pela capacidade intelectual dos recursos humanos, bem como competências desenvolvidas pelas pessoas que nelas trabalham, podendo, assim, atender à demanda pelo imediatismo, pautada pela interconexão dos processos, e também desenvolver a habilidade de adaptar-se às mutações mercadológicas (CHIAVENATO, 2009).

Leite, Godoy e Antonello (2006) destacam a importância da formação, capacitação e autodesenvolvimento daqueles que gerenciam os indivíduos no ambiente de trabalho. A função do gerente mudou ao longo dos anos, que atualmente precisa, além de ajustar-se às novas necessidades de mercado, promovê-la em sua organização e trabalhar em ambientes imprevisíveis.

De acordo com esse contexto, a ênfase em uma formação abrangente e a ampliação das possibilidades de experiência prática durante o curso superior são avaliadas como alternativas para atender à exigência de um perfil multiprofissional e proporcionar a maturidade pessoal e a identidade profissional necessárias para agir em situação de imprevisibilidade, realidade a que estão sujeitas as organizações atuais. Além disso, o investimento no desenvolvimento de competências gerenciais torna-se indispensável para empresas que pretendam se manter competitivas no mercado atual.

$\mathrm{O}$ artigo objetiva identificar quais as competências desenvolvidas em uma empresa construtora com o processo de implantação da Aprendizagem Baseada em Problemas adaptado ao contexto organizacional. A pesquisa foi proposta à empresa estudada, pois a mesma passava por um processo de realocação de funções entre seus engenheiros civis, gestores de obra. $\mathrm{O}$ método da Aprendizagem Baseada em Problemas adaptado ao contexto organizacional foi utilizado para potencializar o desenvolvimento das competências gerenciais de tais profissionais.

Bomfim (2012) diz que o desenvolvimento de competências gerenciais nas organizações permite um avanço para o desenvolvimento do conhecimento, das habilidades e atitudes dos profissionais na busca da qualidade $\mathrm{e}$ produtividade no ambiente de trabalho. Este estudo auxilia na compreensão da importância do desenvolvimento de competências gerenciais na construção civil, seguindo a estratégia metodológica da pesquisa-ação.

\section{Revisão conceitual}

\section{Desenvolvimento de competências}

Segundo Fischer et al. (2008), o conceito de competência surgiu de forma estruturada nas pesquisas de David McClelland no ano de $1973^{1}$. $\mathrm{O}$ pesquisador buscava uma abordagem mais efetiva que os testes de inteligência que eram realizados nos processos de escolha das pessoas

\footnotetext{
${ }^{1}$ CLELLAND, D. C. Testing for Competence Rather Tahn For "Intelligence". American Psychologist, jan. 1973. Disponível em: <http://www.lichaoping.com/wp-content/ap7301001.pdf>.
} Acesso em: 22 mar. 2014 
para as organizações, podendo ser utilizado como referência para a construção e compreensão de instrumentos de gestão de pessoas.

Boyatzis (1982 $2^{2}$ apud DIAS et al., 2008), também considerado um dos precursores a estruturar o conceito de competências, procurava caracterizar as demandas de determinado cargo na organização, para então fixar ações e comportamentos esperados. Analisava também o compromisso da pessoa no ambiente no qual estava inserida, mostrando a importância do contexto para que a pessoa pudesse demonstrar comportamentos aceitáveis.

Boterf (1999) enfatiza a combinação de recursos para a ação em contextos variados, conceituando competência como saber mobilizar e combinar os recursos pessoais (conhecimentos, habilidades e atitudes) e os recursos de seu ambiente pertinente, numa situação específica.

Parry (1998) relaciona competência com desempenho no trabalho e diz que é um cluster de conhecimentos, atitudes e habilidades relacionadas que influem na realização de determinada atividade.

As noções de competências originaram-se da ideia de qualificação dos indivíduos para o trabalho, ou seja, é sustentada na preparação das capacidades voltadas para os processos previsíveis. De acordo com o contexto, o conceito de competências restringe-se à qualificação dos indivíduos, analisadas de acordo com as tarefas a serem desempenhadas em um cargo.

A consolidação da noção de competência inicia-se pela transição do conceito de qualificação para o de competência, período traçado pela identificação das capacidades necessárias na atuação de certa tarefa e obtenção de um melhor desempenho (DIAS et al., 2008)

Tal abordagem foi disseminada no Brasil até o início dos anos 90, associada ao perfil de conhecimentos, habilidades e atitudes (CHA), elemento necessário para garantir desempenho de uma pessoa em determinado cargo (DUTRA, 2001).

Furquim (2011) diz que a abordagem teórica científica acerca do tema competências pode ser classificada em três dimensões. São elas:

(a) competências individuais e/ou gerenciais: referem-se aos indivíduos, e a entrega é resultado de trabalho individual;

2 BOYATZIS, R. E. The Competent Manager. New York: John Wiley \& Sons, 1982. (b) competências coletivas e/ou grupais: fazem referência ao coletivo, e a entrega é resultado de trabalho coletivo; e

(c) competências organizacionais: dizem respeito à estratégia de empresa e são também coletivas.

Ruas, Antonello e Boff (2005) apresentam os seguintes contextos: qualificação para o trabalho e competências, ressaltando suas principais diferenças (Quadro 1). Percebe-se que muitos autores disseminaram a ideia de que competência não está associada ao cargo. De acordo com Ruas, Antonello e Boff (2005), tal perspectiva surge em um contexto de instabilidade da atividade econômica, na qual prevalece a baixa previsibilidade de negócios e a intensificação das estratégias de customização.

O conceito de competência adotado nesta pesquisa refere-se à capacidade de o engenheiro gestor de obras mobilizar, integrar e colocar em ação seus conhecimentos, habilidades e posturas gerenciais, a fim de atingir os objetivos organizacionais.

\section{Modelo da Aprendizagem Baseada em Problemas adaptado ao contexto organizacional}

Kalatzis (2008) afirma que as origens históricas do método ABP, originalmente do inglês Problem Based Learning (PBL), na sociedade atual, têm início no século XX. Conforme Schmidt (1993), na década de 1920, o PBL foi utilizado como método de estudos de casos nos cursos de direito da Universidade de Harvard, nos Estados Unidos.

Barrows e Tamblyn (1976) conceituam a ABP como a aprendizagem que resulta do processo de trabalho orientado para a compreensão ou resolução de um problema. Segundo Schmidt (1993), é uma abordagem para a aprendizagem e a instrução, na qual os estudantes lidam com problemas em pequenos grupos, sob a supervisão de um tutor.

Mamede et al. (2001), por sua vez, conceituam ABP de forma mais ampla, como uma estratégia educacional e uma filosofia curricular, concebendo um processo de aprendizagem no qual os estudantes autodirigidos constroem ativamente seus conhecimentos. Partindo de problemas e trabalhando de maneira colaborativa, os alunos aprendem de forma contextualizada, formulam seus próprios objetivos de aprendizagem e apropriam-se de um saber que adquire um significado pessoal, segundo as disposições internas de cada um.

Kalatziz (2008) diz que a ABP, por ser um modelo instrucional, apresenta definições, características e 
objetivos próprios que o configuram como um método. O mesmo autor diz que a ABP consiste em um método instrucional que faz uso de problemas da vida real, servindo de estímulo para o desenvolvimento do pensamento crítico, de habilidades de resolução de problemas e da aprendizagem dos conceitos que integram $o$ conteúdo programático.

A ABP é vista como um método que dá ênfase ao desenvolvimento de habilidades essenciais como a análise efetiva do problema (BARROWS; TAMBLYN, 1976; WOODS, 1996; ENGEL, 1997) e o estudo autodirecionado. A abordagem centrada no aluno também desenvolve a habilidade de escutar, a de resumir as informações e a de ensinar os outros (BARROWS; TAMBLYN, 1976). Ensinar os colegas é uma habilidade requerida pela maioria dos profissionais, juntamente com a habilidade de trabalhar como parte de uma equipe (BARROWS; TAMBLYN, 1976; WOODS, 1996).

O modelo adaptado, utilizado neste artigo, foi desenvolvido por Neves (2006) em sua tese de doutorado, em que o autor diz que o processo de aprendizagem inicia-se com o compartilhamento do conhecimento individual. Em seguida, a aprendizagem torna-se um processo social, partilhado pelas pessoas do grupo, gerando aprendizagem não só individual como também grupal. Depois da compreensão e da busca da solução para o problema, compartilhada pelo grupo, discutem-se novamente os resultados com outros membros da empresa, motivando a proposição final para a solução do problema em forma de regras e procedimentos, o que cria condições favoráveis para a aprendizagem organizacional.

A utilização da ABP adaptada ao contexto organizacional justifica-se pelo fato de a empresa estudada querer investir na capacitação de seus engenheiros gestores de obra o mais próximo de seu contexto de atuação, ou seja, em seu próprio ambiente de trabalho, compartilhando as experiências entre si, de modo que eles possam discutir a forma como executam suas atividades. Assim, eles podem identificar os conceitos discutidos e relacioná-los à realidade da organização.

O modelo é dividido em cindo etapas: problematização, ação, discussão de solução, planejamento da apresentação da solução e consolidação. O processo inicia-se pela análise detalhada da situação, na qual se define o problema e se estabelecem as proposições iniciais para sua solução. $\mathrm{Na}$ etapa seguinte, individualmente, aplica-se a solução na ação, ocorrendo a reflexão sobre os resultados. Em seguida, na discussão de solução, apresentam-se os resultados para o grupo, havendo questionamentos. Caso alcance o consenso na proposição final, o grupo gera um documento, procedimento ou nova prática e define a forma de apresentação da solução para a empresa. Em caso negativo, discutem-se novamente as proposições. Concluindo essa etapa, realiza-se uma avaliação do ciclo. Na fase de consolidação, apresenta-se o resultado e discute-se com a empresa a proposição final para a solução do problema. Em seguida, define-se uma nova situação problemática e, com isso, inicia-se um novo ciclo. A Figura 1 apresenta a estrutura do modelo adaptado.

Quadro 1 - Noções e características dos contextos qualificação e competência

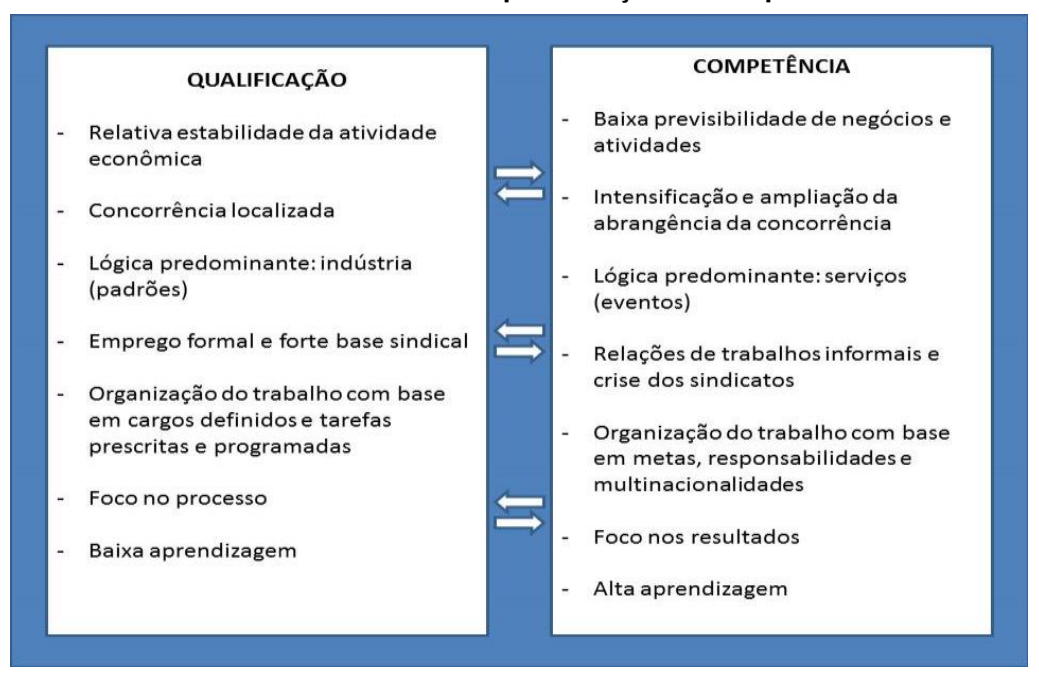

Fonte: Ruas, Antonello e Boff (2005). 
Figura 1 - Modelo de capacitação

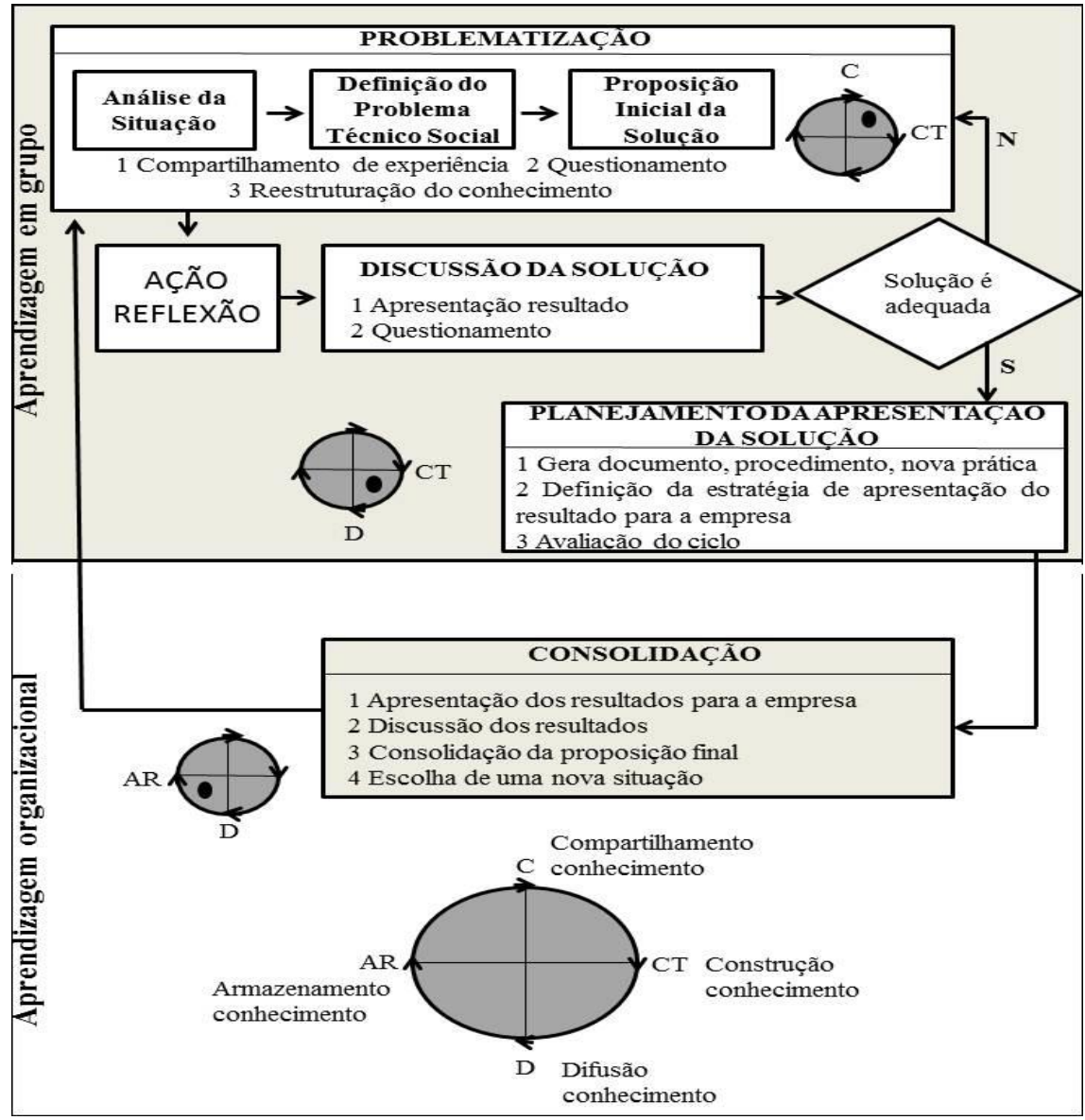

Fonte: Neves (2006).

\section{Metodologia de pesquisa}

\section{Estratégia de pesquisa}

Adotou-se a estratégia de pesquisa-ação, pois ela se desenvolveu com o interesse de mudança e participação de todos os envolvidos no processo. Thiollent (2007) diz que, para que uma pesquisa seja qualificada como pesquisa-ação, é vital a implantação de uma ação por parte das pessoas ou grupos implicados no problema sob observação. Além disso, é necessário que a ação seja não trivial, o que quer dizer uma ação problemática que mereça investigação, sob o ponto de vista científico, para ser elaborada e conduzida. $\mathrm{Na}$ pesquisa-ação os pesquisadores desempenham um papel ativo no equacionamento dos problemas encontrados, no acompanhamento e na avaliação das ações desencadeadas em função dos problemas.

Coghlan e Brannick (2008) consideram que a pesquisa-ação é apropriada quando a questão da pesquisa relaciona-se com descrever $o$ desdobramento de uma série de ações, ao longo do tempo, em dado grupo, comunidade ou organização; para explicar como e por que a ação de um membro de um grupo pode mudar ou melhorar o trabalho de alguns aspectos do sistema; e para entender o processo de mudança ou de melhoria e aprender com ele.

O processo de pesquisa foi concebido de modo participativo, envolvendo o pesquisador e os engenheiros residentes (engenheiros de obra). Diante de uma situação problemática, os engenheiros envolvidos desenvolviam uma ação, que gerava uma reflexão e um planejamento de novas ações para o próximo ciclo. $\mathrm{O}$ pesquisador assumiu o papel de facilitador, o qual proporcionava orientações sobre material didático visando à reestruturação das bases teóricas e a busca pelo conhecimento por iniciativa própria dos engenheiros de obra participantes da pesquisa. Foi responsável também por organizar a dinâmica e os assuntos tratados nas reuniões. Além disso, no decorrer das reuniões, tomou uma postura indagativa perguntando a todo o momento aos gerentes de obra o porquê de ocorrerem os problemas listados em cada ciclo. 
De acordo com Silva e Menezes (2005), a pesquisa do ponto de vista da forma da abordagem do problema é considerada qualitativa, pois considera que pode ser qualificável, o que significa traduzir opiniões e informações para classificá-las e analisá-las, através do uso de recursos e técnicas. Do ponto de vista de seus objetivos, a pesquisa é descritiva, pois visa descrever as características de um fenômeno e envolve o uso de técnicas e coletas de dados com observação sistêmica. Do ponto de vista dos procedimentos técnicos, ela é classificada como pesquisa-ação, pois foi elaborada com a participação e o comprometimento de mudança por parte de todos os envolvidos no estudo.

\section{Delineamento da pesquisa}

A pesquisa empírica desenvolveu-se investigando a implantação da $\mathrm{ABP}$ como o auxílio no desenvolvimento das competências demandadas pela empresa participante da pesquisa. Pode-se afirmar que cada ciclo correspondeu a uma fase de aprendizagem do pesquisador, tendo como ponto de partida a questão de pesquisa. De acordo com os resultados, o pesquisador realizou uma reflexão sobre aprendizagem individual e as competências necessárias aos engenheiros gestores de obra. Tais reflexões foram realizadas, entre um ciclo e outro, com a análise das transcrições das reuniões, em que se analisavam a frequência dos membros do grupo, o crescimento de participação nas reuniões (exposição de opiniões), o comprometimento com as atividades a serem desenvolvidas definidas pelo grupo e a percepção dos participantes com relação aos objetivos da organização. O estudo foi realizado de acordo com as etapas apresentadas na Figura 2. A etapa de identificação das competências ocorreu por meio de entrevistas com a utilização de questionários estruturados, aplicados com os engenheiros gestores de obras e seus subordinados (técnicos de segurança no trabalho, técnicos administrativos, estagiários e mestres de obra). $\mathrm{O}$ questionário avaliou as competências relacionadas à condução de reunião, trabalho em equipe, gerenciamento de conflitos, liderança de grupo, capacidade de resolução de problemas, tomada de decisão, análise crítica, tomada de decisão consensual e comunicação, através de notas de 0 (ruim) a 5 (excelente), atribuídas de acordo com a percepção do trabalho desenvolvido por seus engenheiros gestores de obra.

O estudo exploratório teve início com a identificação e a análise do perfil dos participantes da pesquisa a partir dos dados coletados por meio de questionários. Nesse primeiro momento, o pesquisador teve informações como tempo de formação em engenharia, tempo de atuação no mercado de trabalho, tempo de trabalho na empresa atual, além dos tipos de obras em que os envolvidos atuam. $\mathrm{O}$ estudo exploratório se desenvolveu através de reuniões semanais, com duração média de 2 horas, por um período de 3 meses. O grupo foi formado por 10 engenheiros gestores de obra, mais o pesquisador (facilitador) e o orientador (coordenador), de acordo com a Figura 3.

Cada tema correspondeu a um ciclo de implantação da ABP. Tais ciclos iniciaram-se com a reunião em que era debatido e analisado cada problema referente ao tema daquele ciclo. Inicialmente, trabalhou-se a problematização, analisando a situação, definindo o problema e buscando proposições iniciais para a solução do problema, através do compartilhamento de experiências, questionamentos e reestruturação do conhecimento (pesquisas bibliográficas, internet, etc.). Posteriormente, foi realizada uma ação reflexão, em que se discutiu a possível solução encontrada pelo grupo através da apresentação do resultado e questionamentos. Essa fase da ação ficou comprometida no processo, porque o grupo não colocou em prática as possíveis soluções explanadas. Foi analisado se a solução seria adequada ou não. Caso o grupo entendesse que a solução não era adequada, voltava-se para a reestruturação da problematização; caso contrário, partia-se para o planejamento da apresentação da solução. Esse planejamento envolveu a criação de documentos, procedimento e novas práticas, além de ter sido definida a estratégia de apresentação do resultado para a empresa (diretores). No fechamento do ciclo trabalhou-se a consolidação, em que foi realizada a apresentação dos resultados para a empresa, a discussão dos resultados, a consolidação da proposição final, e culminava na escolha de uma nova situação (tema), iniciando-se um novo ciclo. A duração de cada ciclo variou de acordo com a necessidade do grupo e a condução do pesquisador.

\section{Tratamento dos dados}

Após o período de implantação da $\mathrm{ABP}$ na empresa, iniciou-se o tratamento dos dados. Tal análise buscou fundamentar-se nas observações do pesquisador no decorrer das reuniões, levando em consideração aspectos de aprendizagem e gestão organizacional de acordo com os relatos dos engenheiros residentes participantes do grupo. 
Figura 2 - Delineamento da pesquisa

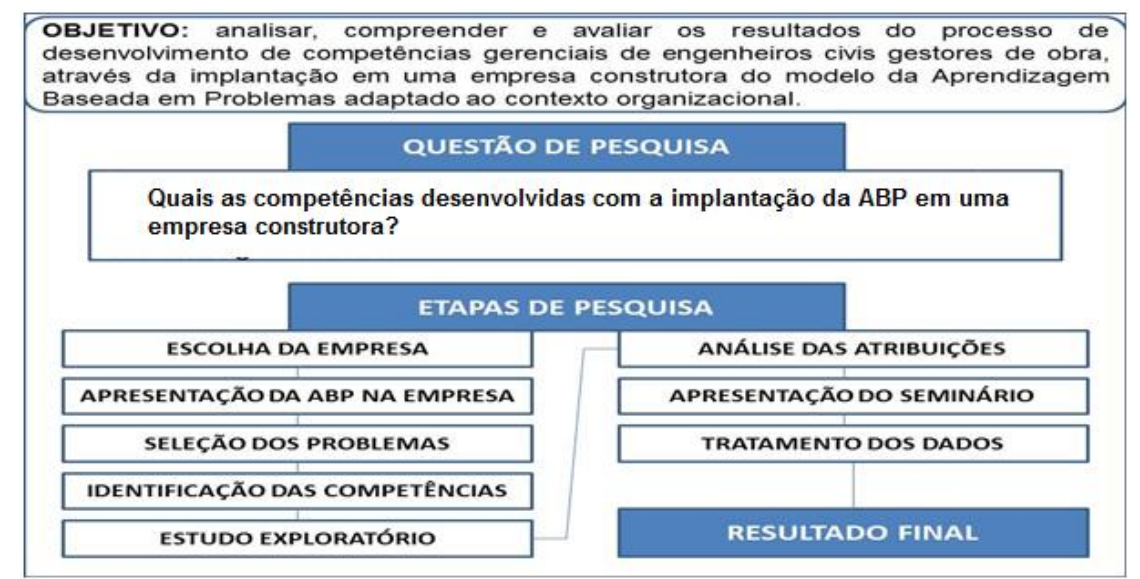

Figura 3 - Estrutura do estudo exploratório

ESTUDO EXPLORATÓRIO

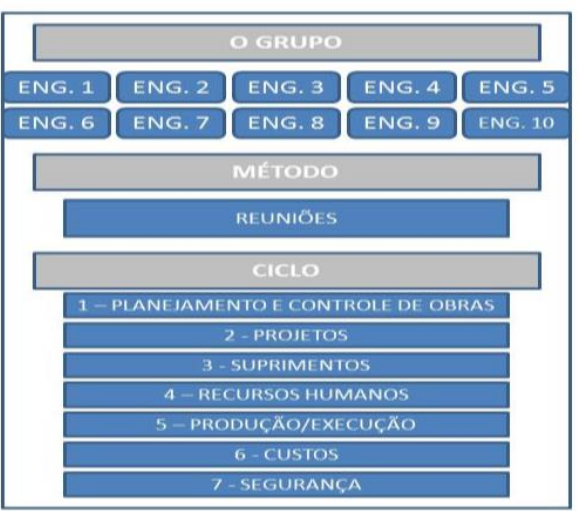

O processo de análise dos dados iniciou-se com a leitura das transcrições das reuniões. Utilizaram-se trechos das reuniões, as entrevistas realizadas e documentos da empresa como organograma, procedimentos e alguns indicadores, objetivando cruzar as evidências existentes. A história do grupo no decorrer das reuniões foi contada de forma sequencial e cronológica, apresentando os fatos ocorridos julgados importantes para o pesquisador, objetivando analisar o processo de aprendizagem organizacional, o desenvolvimento de competência gerencial e aspectos da gestão organizacional da empresa.

Para facilitar a análise foram definidos os seguintes construtos:

(a) análise do contexto organizacional;

(b) análise da aprendizagem individual;

(c) análise da aprendizagem coletiva; (d) análise da aprendizagem organizacional; e

(e) análise do sistema de gestão da empresa.

São apresentados no Quadro 2 suas definições, as principais fontes de evidências, seus instrumentos e como foram identificados. As definições dos construtos foram baseadas na revisão bibliográfica, as fontes de evidências foram as transcrições das reuniões, as entrevistas realizadas com os diretores, subordinados e os engenheiros residentes (gerentes de obra), a observação direta in loco, as anotações pessoais do pesquisador e a análise de documentos internos da empresa serviram para enriquecer o processo de análise. As evidências foram elaboradas durante o processo de transcrição das reuniões e leitura delas, objetivando identificar expressões e palavras empregadas pelos engenheiros residentes em suas falas durante as reuniões. Essa identificação foi importante, pois guiou o pesquisador na análise das entrevistas. 
Quadro 2 - Fonte de evidências (Continua)

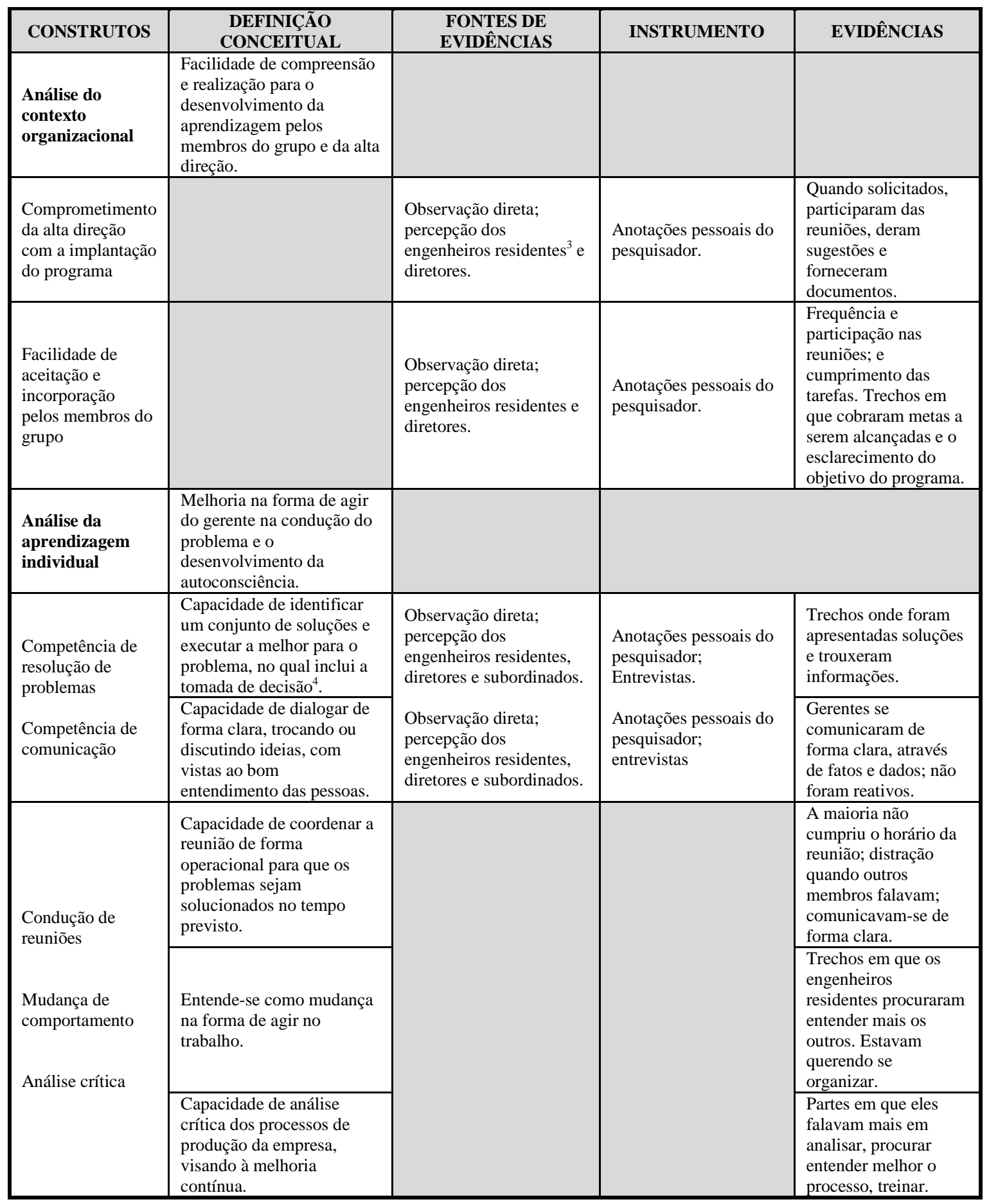

\footnotetext{
${ }^{3}$ Nomenclatura da empresa para engenheiro de obra.

${ }^{4}$ Capacidade de tomar decisões fundamentadas em fatos e dados, obtendo e implementando soluções de acordo com os objetivos.
} 
Quadro 2 - Fonte de evidências (Continuação)

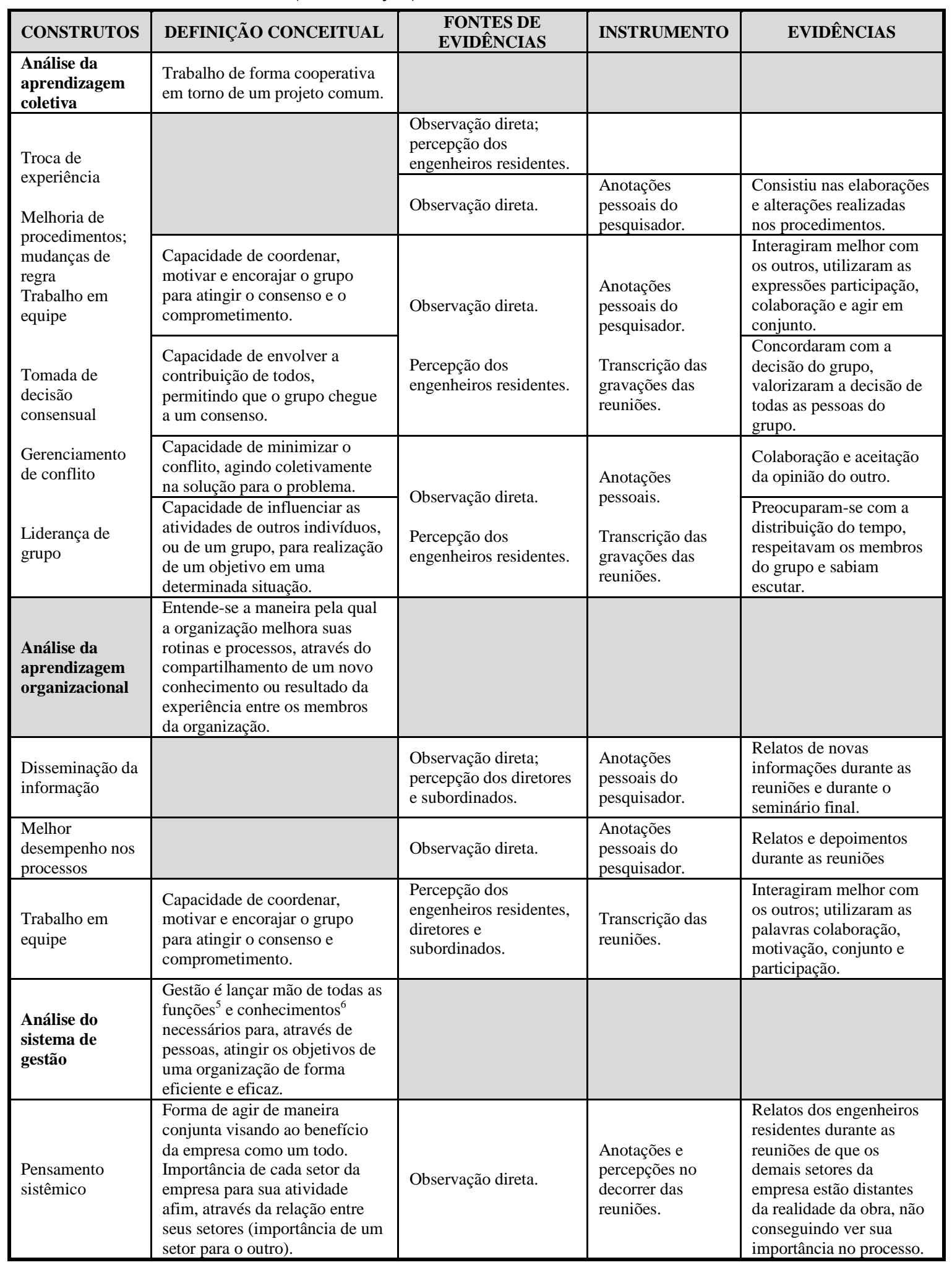

\footnotetext{
${ }^{5}$ Técnica, contábil, financeira, comercial, segurança e administração.
}

${ }^{6}$ Psicologia, antropologia, estatística, mercadologia, ambiental, etc. 
Análise dos resultados

\section{Problemas listados em cada tema}

Inicialmente, foram analisados os problemas listados para cada tema, que representavam a prioridade a ser trabalhada de acordo com o interesse da empresa. Percebeu-se que grande parte dos problemas listados em todos os temas estava diretamente relacionada ao planejamento e controle de obras. O Quadro 3 apresenta os problemas citados na reunião de seleção dos problemas.

\section{Análise da identificação das competências}

Para a identificação das competências gerenciais foram consideradas características pessoais e habilidades específicas do trabalho, além de algumas informações adicionais coletadas nas entrevistas realizadas entre os engenheiros e seus subordinados. A Figura 4 apresenta a média dos resultados dos engenheiros gestores de obra da empresa. Percebe-se que os gerentes (EU) tiveram uma visão de suas próprias competências que difere da opinião de sua equipe administrativa (OUTROS), que foram mais críticos sobre as competências dos engenheiros de obra (Quadro 4).

\section{Quadro 3 - Lista de problemas citados}

\begin{tabular}{|c|c|}
\hline PLANEJAMENTO & PROJETOS \\
\hline $\begin{array}{l}\text { - Falta de reuniões com a administração da obra para } \\
\text { definir estratégia de execução } \\
\text { - Equipe específica de planejamento de obra } \\
\text { - Integração maior entre áreas e equipe de obra } \\
\text { - Planejamento de obra sem a participação das } \\
\text { equipes de obra } \\
\text { - Falta de padronização nos setores e processos da } \\
\text { empresa } \\
\text { - Procedimentos, treinamento e sinalização em todas } \\
\text { as obras } \\
\text { - Padronização de documentação } \\
\text { - Procedimento de portaria (deficiente) } \\
\text { - Padronização de função por capacete } \\
\text { - Dimensionamento de equipes verticais para suprir as } \\
\text { necessidades da torre }\end{array}$ & $\begin{array}{l}\text { - Incompatibilidade de projetos e suas constantes } \\
\text { mudanças } \\
\text { - Adequação dos projetos à realidade de nossa região } \\
\text { - Falta de análise crítica dos projetos liberados para } \\
\text { obra } \\
\text { - Incompatibilidade de projetos } \\
\text { - Compatibilização de projetos } \\
\text { - Atraso da entrega de projetos na obra } \\
\text { - Projetos referentes ao canteiro (instalações } \\
\text { provisórias) } \\
\text { - Demora na entrega dos projetos }\end{array}$ \\
\hline $\begin{array}{c}\text { RH E SUPRIMENTOS } \\
\end{array}$ & $\begin{array}{l}\text { PRODUÇÃO/EXECUÇÃO } \\
\end{array}$ \\
\hline $\begin{array}{l}\text { - Baixa capacidade operacional do setor de compras } \\
\text { - Baixa qualidade dos produtos, ferramentas, } \\
\text { equipamentos e materiais adquiridos } \\
\text { - Padronização no cadastro de insumo } \\
\text { - Demora na aprovação de materiais no sistema } \\
\text { - Demora na chegada de materiais } \\
\text { - Falta de material } \\
\text { - Demora na compra/entrega } \\
\text { - Falta de programação do engenheiro da obra } \\
\text { - Falta de interesse do engenheiro }\end{array}$ & $\begin{array}{l}\text { - Padronização dos procedimentos executivos de } \\
\text { serviços e critérios de avaliação para pagamento da } \\
\text { produção } \\
\text { - Falta de mão de obra } \\
\text { - Falta de qualificação } \\
\text { - Falta de investimento em mão de obra } \\
\text { - Equipes de obra muito numerosas que causam } \\
\text { dispersão de objetivos e metas } \\
\text { - Qualidade de serviços de empreiteiros } \\
\text { - Falta de mão de obra qualificada } \\
\text { - Falta de procedimentos operacionais }\end{array}$ \\
\hline $\begin{array}{l}\text { CUSTOS } \\
\end{array}$ & SEGURANÇA \\
\hline $\begin{array}{l}\text { - Otimização da mão de obra com inserção de novas } \\
\text { tecnologias } \\
\text { - Verbas não compatíveis para realização dos serviços } \\
\text { - Orçamento limitado } \\
\text { - Rescisão contratual de funcionário } \\
\text { - Demora na liberação de notas } \\
\text { - Falta de critério para recebimento de serviços }\end{array}$ & $\begin{array}{l}\text { - Criar procedimentos em todas as fases da obra } \\
\text { - Falta de padronização das exigências da DRT } \\
\text { - Proteções } \\
\text { - EPI (empreiteiras) } \\
\text { - Documentação da empresa (laudos, projetos, } \\
\text { procedimentos) } \\
\text { - Não conservação da área de vivência } \\
\text { - Utilização de EPIs } \\
\text { - Fornecimento de copo de alumínio e garrafa térmica } \\
\text { - Não cumprimentos de normas quanto à utilização }\end{array}$ \\
\hline
\end{tabular}

164 Martins, V. W. B; Neves, R. M. das; Macêdo, A. N. 
Figura 4 - Média das avaliações de competências gerenciais

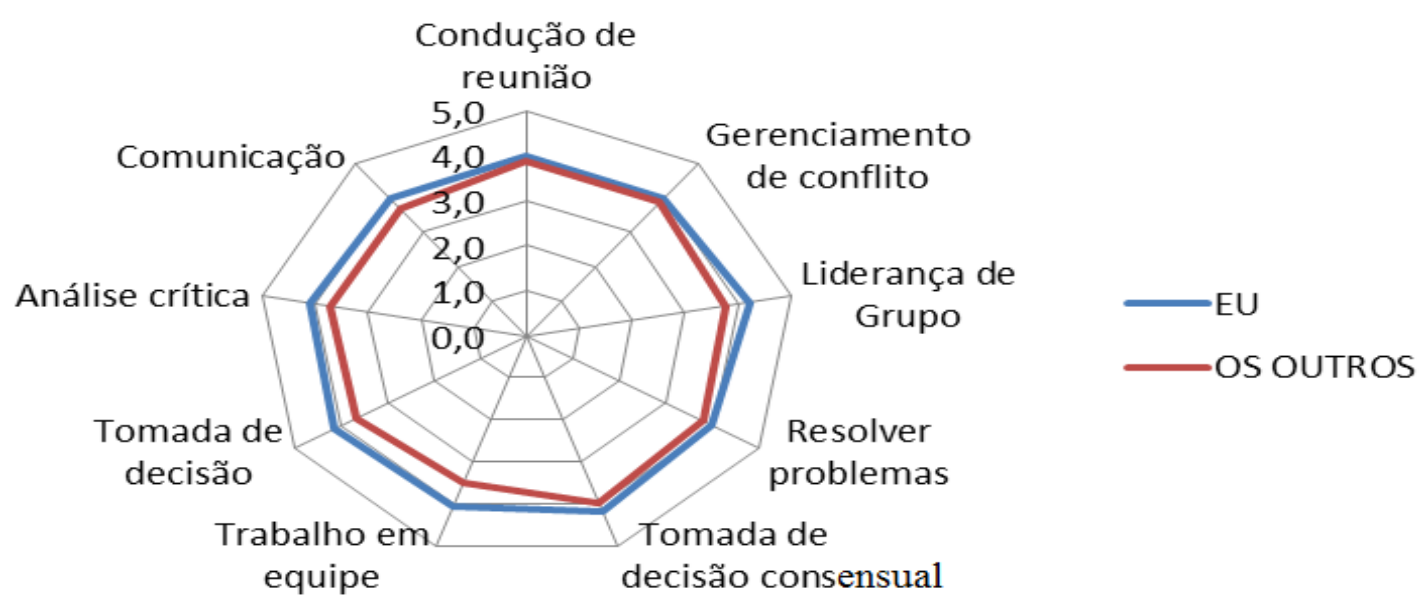

Quadro 4 - Resumo das avaliações

\begin{tabular}{|l|c|c|}
\hline \multicolumn{1}{|c|}{ Tópicos abordados } & Eu & Os outros \\
\hline Condução de reunião & 4,0 & 3,9 \\
\hline Gerenciamento de conflito & 4,0 & 3,9 \\
\hline Liderença de grupo & 4,2 & 3,8 \\
\hline Resolver problemas & 4,0 & 3,8 \\
\hline Tomada de decisão consensual & 4,2 & 4,0 \\
\hline Trabalho em equipe & 4,0 & 3,5 \\
\hline Tomada de decisão & 4,1 & 3,7 \\
\hline Análise crítica & 4,1 & 3,7 \\
\hline Comunicação & 4,0 & 3,7 \\
\hline
\end{tabular}

Observa-se que as maiores divergências de resultados estão nos itens liderança de grupo, trabalho em equipe, tomada de decisão e análise crítica, logo tais competências necessitam de maior atenção em seu processo de desenvolvimento. No decorrer do estudo exploratório através da percepção do pesquisador in loco nas reuniões, foi identificado que os engenheiros apresentam uma grande capacidade técnica, porém as dificuldades no gerenciamento de pessoas foram evidentes.

\section{Estudo exploratório}

\section{Ciclo 1: planejamento e controle de obras}

Neste ciclo, foram realizadas seis reuniões semanais, em que primeiramente se abordaram os problemas existentes atualmente nas obras e quais as suas possíveis soluções. Abaixo serão apresentados os assuntos abordados em cada reunião.

A reunião 1 contou com a participação de 9 engenheiros residentes e se iniciou definindo o contrato do grupo, em que foram esclarecidas as normas para as reuniões, tolerância de faltas, o comprometimento e a confidencialidade das informações. Em seguida, foi realizada a leitura dos problemas relacionados ao planejamento, listados na reunião de seleção dos problemas, e foi perguntado aos engenheiros residentes o porquê de ocorrer tais problemas. Os engenheiros falaram da falta de reuniões com a administração da obra para definição de estratégias de execução dos serviços. $\mathrm{O}$ pesquisador percebeu que apenas 4 engenheiros residentes apresentavam uma postura mais ativa, expressando seu entendimento e opinião sobre o assunto. De acordo com as respostas, o pesquisador solicitou para próxima reunião um fluxograma do sistema de planejamento, objetivando identificar os envolvidos e as partes do processo de planejamento da empresa. A reunião se encerrou com a definição da data, local e horário da próxima reunião, e com as responsabilidades de cada um para o próximo encontro, em que se definiu que seria enviado aos engenheiros um termo de referência sobre planejamento, para que fosse realizada a leitura do material, objetivando dar um embasamento teórico aos participantes do grupo sobre o tema planejamento. 
A reunião 2 contou com a participação de 9 engenheiros residentes e iniciou-se com a apresentação do fluxograma das etapas atuais de planejamento da empresa. Nesse momento, o pesquisador pôde identificar e analisar todas as etapas e envolvidos no processo de planejamento. $\mathrm{O}$ facilitador perguntou aos engenheiros:

$\mathrm{Na}$ opinião de vocês, quais são os indicadores relevantes em um sistema de planejamento?

Por que vocês acham que o planejamento não está dando certo?

Os engenheiros, de uma maneira geral, falaram que acreditam no planejamento de uma forma mais objetiva.

[...] precisa ser eliminado do planejamento as ferramentas que não agregam valor ao processo [...] existem vários indicadores hoje que não servem pra muita coisa [...]. (Engenheiro residente 1).

Identificou-se certo desconforto por parte dos engenheiros residentes com relação às ferramentas utilizadas no processo de planejamento da empresa. Muitos não sabiam transformar os indicadores que dispunham em informações relevantes para uma boa gestão de obra. O facilitador, em seguida, perguntou quem havia lido o termo de referência sobre planejamento que tinha sido enviado a todos.

\section{[...] não encontrei tempo para realizar a leitura. (Engenheiro residente 1).}

\section{[...] eu até comecei a ler, mas o material é muito grande com muitas páginas [...]. (Engenheiro residente 3).}

[...] o material precisa ser mais objetivo, ele é muito acadêmico. (Engenheiro residente 7 ).

Ficou claro nesse momento que os engenheiros ainda não estavam familiarizados com a metodologia do processo de implantação da ABP. A reunião encerrou-se com a definição do horário, data e local da próxima reunião e os assuntos que seriam tratados. Ficou decidido que o termo de referência seria apresentado na próxima reunião pelo coordenador do grupo.

A reunião 3 contou com a participação de apenas 5 engenheiros residentes, ou seja, com $50 \%$ dos participantes do grupo, o que demonstrou certo desinteresse/resistência com relação ao programa da ABP. A reunião iniciou-se com a apresentação do termo de referência elaborado pelo coordenador do grupo, o qual abordou conceitos, definições e ferramentas para planejamentos de longo (nível estratégico), médio (nível tático) e curto prazo (nível operacional). Ao final da apresentação, o coordenador perguntou ao grupo como introduzir o termo de referência criado no fluxograma atual da empresa. Iniciou-se então uma discussão de quais indicadores e ferramentas seriam relevantes para o processo de planejamento. Foram citadas as práticas de programações de serviços (OS), planejamento de execução de serviços (PES), indicadores de avaliação de empreiteiros e introdução da prática da reunião de comprometimento. A reunião encerrou-se com a definição da data, horário e local da próxima reunião. Ficou sobre a responsabilidade do grupo pesquisar e trazer modelos de agenda para ser utilizada na prática da reunião de comprometimento.

A reunião 4 contou com a participação de 8 engenheiros residentes. O coordenador do grupo iniciou a reunião perguntando por que planejar é importante e se o grupo estava na porcentagem dos engenheiros que acreditam ou não no planejamento.

\section{[...] é importante para nos dar um horizonte [...] sem planejamento não saberíamos se estamos atrasados ou não com o andamento da obra. (Engenheiro residente 4).}

Foram apresentados modelos de agenda trazidos pelo grupo e decidiu-se criar um procedimento para atender às necessidades de planejamento que cada participante expressou, objetivando minimizar as dificuldades em seguir o planejamento atual da empresa. A reunião encerrou-se com a definição do horário, data e local do próximo encontro, além das deliberações dos participantes para a reunião seguinte, em que o facilitador e coordenador ficaram encarregados de enviar um modelo de procedimento de planejamento e o grupo ficou encarregado de pesquisar e definir as melhores práticas a serem inseridas no procedimento.

A reunião 5 contou com a participação de 9 engenheiros residentes. Teve como objetivo a elaboração do procedimento de planejamento, com a participação em conjunto de todos os envolvidos no grupo. A reunião iniciou-se com o coordenador perguntando se alguém fez a leitura do procedimento enviado e se fizeram alguma inserção/modificação no procedimento.

\section{[...] eu fiz algumas observações e anotações, porém não modifiquei nada, eu trouxe aqui pra gente montar em conjunto o nosso. (Engenheiro residente 1).}

A reunião se desenvolveu com a elaboração do procedimento, em que os membros do grupo apresentavam sua sugestão e entendimento a 
respeito de cada item a ser incluído, alterado ou retirado do procedimento. $\mathrm{O}$ pesquisador percebeu que alguns engenheiros não opinavam na elaboração do documento. $\mathrm{O}$ procedimento objetivava estabelecer as fases do planejamento e o controle do andamento físico das obras. A reunião encerrou-se com o procedimento todo redigido e formatado, porém faltava acrescentar as ferramentas anexas para atender ao que foi definido no procedimento. Esta foi a tarefa a ser apresentada na próxima reunião. Cada engenheiro ficou encarregado de trazer ferramentas que atendessem à necessidade do que tinha sido definido no procedimento.

A reunião 6 contou com a participação de 8 engenheiros residentes. O coordenador do grupo não esteve presente, e a reunião foi conduzida pelo facilitador. O objetivo da reunião era finalizar o procedimento de planejamento com a inclusão das ferramentas anexas para atender às diretrizes definidas em conjunto. A reunião iniciou-se com o grupo questionando sobre o andamento do programa, seus reais objetivos e aonde se queria chegar com a implantação dele na empresa.

\section{[...] Confesso que naquele procedimento que a gente fez na reunião passada eu não identifiquei ali muito a empresa. (Engenheiro residente 6).}

[...] Acho que tu deves concordar que a gente tá ai já na sexta reunião e ainda não conseguimos sair de um ponto, o do planejamento. [...] precisamos enxergar uma meta que a gente ainda não tem hoje. (Engenheiro residente 1).

Percebeu-se que o grupo ainda não tinha entendido o real sentido da implantação do programa da ABP. A alta gerência da empresa, quando questionada pelos participantes do programa, teria passado a informação de que o objetivo seria aumentar o andamento físico da obra de $1,5 \%$ para $3 \%$ ao mês, fato que causou certo desentendimento entre o que estava sendo feito e o objetivo definido pela direção da empresa.

[...] a gente fica esperando uma coisa que não tá chegando. E começa a criar esse desânimo, essa frustração, porque a gente não tem a expectativa de um retorno imediato. (Engenheiro residente 3 ).

[...] se esse objetivo fosse colocado no momento da primeira reunião, que era avançar a produtividade, eu acho que o item produçãolexecução nunca ia ficar como sexto item na prioridade, com certeza ele deveria tá entre o 3 primeiros a serem trabalhados [...]. (Engenheiro residente 1).
A reunião encerrou-se com a definição de uma nova ordem de temas a serem trabalhados, os quais foram Projetos, RH \& Suprimentos, Produção/execução, Custos e Segurança. Ficou decidido que planejamento era um tema que abordava todos os demais temas, então, na reunião seguinte, iniciaram-se os assuntos referentes a projetos. O procedimento que estava sendo elaborado sobre planejamento não foi finalizado.

\section{Ciclo 2: projetos}

Foram realizadas três reuniões semanais, em que primeiramente se abordaram os problemas existentes atualmente nas obras e quais suas possíveis soluções. A seguir são apresentados os assuntos abordados em cada reunião.

A reunião 1 contou com a participação de 7 engenheiros residentes. Iniciou-se com a leitura dos problemas listados e com a discussão de suas possíveis soluções. A reunião se desenvolveu com as opiniões dos engenheiros residentes sobre a criação de um setor específico de projetos na empresa e, consequentemente, sobre a criação da figura do coordenador de projetos para solucionar ou minimizar os problemas apresentados.

O coordenador do grupo perguntou aos engenheiros residentes o que cabia a eles com relação a projetos.

[...] cobrar os projetos definidos, né, ou pelo menos já terminados no tempo hábil [...]. (Engenheiro residente 1).

A partir desse momento o grupo decidiu criar um procedimento para projetos que solucionasse as problemáticas existentes.

[...] temos que pensar em uma solução, ver qual o procedimento que vamos adotar pra solucionar isso ai, que tem problemas a gente sabe, então vamos pensar como revolver isso. (Engenheiro residente 1).

$\mathrm{O}$ coordenador do grupo perguntou o que mais incomodava os engenheiros com relação a projetos, o que é preciso haver para que esses problemas listados não ocorram.

\section{[...] acredito que criando um setor específico de projetos, criando a figura do coordenador específico de projetos e criar um sistema de avaliação de fornecedores já resolveria grande parte dos problemas [...]. (Engenheiro residente 6).}

Percebeu-se, mais uma vez, que a causa dos problemas nunca estava sob a responsabilidade das ações dos engenheiros, e sim em fatores externos à obra. O facilitador relembrou que o procedimento a ser criado seria aplicado na empresa, para que, 
através dos resultados da ação (aplicação), o procedimento fosse validado ou não. A reunião encerrou-se com o coordenador do grupo lembrando que o procedimento deveria ser objetivo e que abordasse ferramentas que pudessem ser aplicadas pelos próprios engenheiros em suas obras. Ficou definido que seria elaborado em conjunto o procedimento na próxima reunião, de acordo com o modelo que seria enviado pelo facilitador durante a semana. Mais uma vez alguns participantes do grupo não conseguiram se desligar de assuntos externos à reunião, atendendo ao celular constantemente.

A reunião 2 contou com a participação de 6 engenheiros residentes e objetivava ajustar, de acordo com os interesses da organização, o modelo de procedimento que tinha sido enviado pelo facilitador durante a semana. Iniciou-se a elaboração do procedimento em conjunto com os participantes expondo suas opiniões sobre cada item do procedimento como objetivo, documentos de referência, responsabilidades e ferramentas.

\section{[...] só pra relembrar tá, hoje vamos tentar adequar esse procedimento de acordo com aquelas 3 situações que discutimos na reunião passada. (Facilitador). \\ [...] Que é a figura do coordenador de projetos, a criação do setor de projetos e a função do engenheiro de obra com relação a projetos. (Coordenador).}

Nesse momento, ficou claro que na empresa não havia uma definição do que seriam as atribuições dos engenheiros de obra, pois os participantes do grupo encontraram dificuldades em citar suas responsabilidades com relação a questões de projetos. A reunião seguiu com os ajustes no procedimento visando justificar a criação da figura do coordenador e o setor específico para projetos. Encerrou-se a reunião faltando apenas os ajustes nas ferramentas anexas ao procedimento, o que ficou para a reunião seguinte.

A reunião 3 contou com a participação de apenas $50 \%$ do engenheiros participantes do grupo e objetivava finalizar o procedimento, incluindo as ferramentas anexas que iriam atender às necessidades que haviam sido definidas pelo grupo. A reunião se desenvolveu com as discussões das melhores práticas e ferramentas a serem incluídas no procedimento. Ao final da reunião, acordou-se que o facilitador iria formatar e finalizar o procedimento incluindo as ferramentas escolhidas em conjunto e enviaria ao grupo para que fosse validada por todos. O fechamento do ciclo se consolidou com a apresentação do procedimento para a alta direção da empresa. Tal apresentação foi conduzida por um representante do grupo.

\section{Ciclo 3: suprimentos}

Neste ciclo, foi realizada apenas uma reunião. Abordaram-se assuntos referentes aos problemas nos canteiros de obra e suas possíveis soluções.

A reunião contou com a participação de 8 engenheiros residentes. Iniciou-se com a leitura da lista de problemas e com a discussão sobre possíveis soluções. A discussão se desenvolveu em cima da ideia de descentralizar o setor de compras do escritório e levar para o canteiro de obra.

Na minha opinião cada obra deveria ter o seu próprio setor de compras. (Engenheiro residente 6).

[...] ampliar e estruturar o setor de compras seria uma saída, agora criar um setor de compras na obra, pode ter certeza que isso não será aprovado, é um perfil da empresa. (Engenheiro residente 8).

De acordo com a discussão inicial sobre a criação do setor de compras na obra, foram relatados por um engenheiro participante do grupo os problemas que ele tinha em sua obra com relação aos suprimentos. Foi citada a falta de qualidade do material.

[...] o foco do responsável pelo Compras não é esse e sim planejamento e gestão [...] então ele tá liberando os pedidos e os caras estão comprando [...] sem visão de obra acabam comprando material sem qualidade, porque não tem ninguém para orientá-los. (Engenheiro residente 6).

A discussão seguiu em cima da reestruturação do setor de compras e na definição das atribuiçõos dos envolvidos em tal processo.

Devemos melhorar o setor de compras, definindo as atribuições das pessoas de lá, esse aqui é só pra comprar, esse outro só pra fazer levantamento e esse outro pra andar nas obras e se comunicar com os almoxarifes. (Engenheiro residente 4).

Tá faltando um setor de compras mais amplo e uma padronização dos materiais para todas as obras. (Engenheiro residente 1).

De acordo com as situações e pretensões de melhorias apresentadas pelo grupo, o facilitador lembrou os problemas listados sobre suprimentos baixa capacidade operacional do setor de compras, baixa qualidade dos produtos, ferramentas e equipamentos adquiridos, falta de padronização no 
cadastro de insumo, demora na aprovação de materiais no sistema e demora na chegada de materiais -, o que demonstrou um problema no processo de compra de materiais da empresa.

Eu volto a dizer o problema é o processo, o processo que tem que melhorar. (Engenheiro residente 4).

Eu acho que tá faltando a aproximação do almoxarife com o setor de compras. (Engenheiro residente 8).

Percebeu-se nesse momento que a empresa tinha problemas de gestão, em que se identificou que seus setores não conseguiam trabalhar de forma sistêmica, ou seja, desenvolvendo suas atividades para atender aos interesses da organização como um todo. Isso foi bastante evidenciado durante a reunião.

[...] Eu acho que todo o nosso processo é falho. (Engenheiro residente 6).

Além das evidências de um sistema de gestão não definido, pôde-se identificar o não comprometimento dos envolvidos no processo de compras com as obras diretamente, pois os compradores não enxergavam sua importância dentro do processo como um todo.

\section{[...] é exatamente essa falta de uma gestão que nos desestimula [...]. (Engenheiro residente 4).}

Os membros do grupo não conseguiam assumir as responsabilidades sobre os problemas de suprimentos existentes na empresa. Relatos durante a reunião enfatizaram que, na visão deles, os problemas eram causados sempre por fatores externos à obra.

Problemas extra obra se fossem
solucionados eliminariam $99 \%$ dos
problemas de obra. (Engenheiro residente
6).
Nos preocupamos tanto com problemas
extra obra, que não conseguimos
identificar os problemas de obra.
(Engenheiro residente 8).

A reunião encerrou-se com o coordenador perguntando ao grupo se, sendo implantado o procedimento definido em projetos e tudo isso que havia sido comentado em suprimentos, iria se conseguir resolver os problemas de obra existentes. Essa pergunta fez os engenheiros perceberem que eles estavam cada vez mais justificando os problemas a fatores externos à obra, não assumindo responsabilidade sobre eles. Para o encerramento do ciclo ficou decidida a criação de um procedimento para atender às necessidades de suprimentos, porém a elaboração seria feita pelo coordenador em conjunto com o facilitador, e o grupo iria validar o procedimento elaborado antes da apresentação para a alta direção da empresa. O ciclo encerrou-se com o grupo validando o procedimento elaborado e culminou com a apresentação dele por um engenheiro residente para a alta direção da empresa, com a participação do gerente de planejamento, dos gerentes de obra e da gerente de RH.

\section{Ciclo 4: recursos humanos}

Como no ciclo anterior, foi realizada apenas uma reunião. Estiveram presentes 7 engenheiros residentes. A reunião se desenvolveu com discussões referentes à melhoria da sistemática de contratação, investimento em treinamento e capacitação de pessoal, e criação de um plano de cargos e salários, além de mais uma vez voltar à tona o problema da definição das atribuições de todos os colaboradores envolvidos no processo da empresa.

[...] não vejo o setor de Rh preocupado com capacitação da nossa mão de obra, eles esperam muito que isso parta da obra, vejo o setor muito distante da realidade da obra. (Engenheiro residente 6).

[...] o nosso Rh é muito distante da obra, ele tem uma postura assim tipo não é comigo, o problema é da obra, com eles não tem aquilo assim, não o problema é nosso, vamos junto. (Engenheiro residente 1).

Foi relatado que a empresa está passando por uma reestruturação do setor de RH devido ao crescimento rápido do número de funcionários. Atualmente, a empresa conta com uma gerente de RH, uma psicóloga e a equipe de apoio com técnicos administrativos e estagiários. Foi ressaltado na reunião que esse departamento atende a todo o grupo da empresa, ou seja, não somente à construtora. Com relação às atribuições das pessoas envolvidas no processo de contratação os engenheiros, disseram ter dificuldades em saber para quem solicitar a contratação de pessoal, relataram as barreiras impostas pela empresa e a demora na contratação de mão de obra.

A empresa exige o ensino médio para contratar um pedreiro [...] eu não quero um pedreiro para saber ler e sim para trabalhar e desempenhar a sua função. (Engenheiro residente 4). 
O cara pode não ter o segundo grau, mas pode ter uma vida como carpinteiro com duas carteiras cheias, eu quero um cara bom de trabalho e não um que venha escrever um livro. Eles alegam que é uma norma da empresa, só que compromete o nosso andamento de obra e eles não veem isso. (Engenheiro residente 6 ).

De acordo com a discussão sobre os entraves de contratação de pessoal, voltou à tona na reunião a questão da capacitação e qualificação da mão de obra da empresa. $\mathrm{O}$ grupo foi unânime em afirmar que a empresa precisa investir mais em treinamento de pessoal. Além disso, foi enaltecida a necessidade de aproximar o setor de RH com a obra. Outro problema relatado durante o ciclo foi a falta de um plano de cargos e salários da empresa e de uma padronização do índice de produtividade a ser pago.

Um grande problema nosso, é a empresa pagar um salário defasado com relação ao mercado para um encarregado. (Engenheiro residente 6).

A solução pra isso é criar o que a empresa ainda não tem hoje, que é um plano de cargos e salários. (Engenheiro residente 1).

Da mesma forma do ciclo anterior, ficou decidido que seria elaborado posteriormente pelo facilitador e pelo coordenador um procedimento para atender às necessidades citadas em relação a Recursos Humanos e que o mesmo seria validado pelos membros do grupo. Encerrou-se o ciclo enfatizando a importância de um sistema de gestão sólido e bem definido dentro da empresa, além de se terem as atribuições a serem desempenhas pelos envolvidos no processo de forma clara. O fechamento do ciclo se consolidou com a apresentação do procedimento elaborado e validado pelo grupo para a alta direção da empresa, em que participaram o gerente de planejamento, dois gerentes de obra e a gerente de RH, tal apresentação foi conduzida por um representante do grupo.

\section{Conclusões do estudo exploratório}

Durante o desenvolvimento dos ciclos, as dificuldades de implantação da ABP na empresa foram evidentes. $\mathrm{O}$ grupo não conseguiu quebrar a resistência em assumir as responsabilidades sobre os problemas apresentados, o que comprometeu a tomada de ação do grupo no processo de aprendizagem e, consequentemente, no desenvolvimento de competências gerenciais.

Nota-se que não foram trabalhados os temas de produção/execução, custos e segurança conforme definido no capítulo de metodologia. Isso ocorreu devido ao fato de o setor da construção civil ter entrado em greve, inviabilizando o desenvolvimento de tais ciclos. Os gráficos abaixo foram elaborados baseando-se nas análises realizadas das transcrições das reuniões e considerando as palavras-chave definidas nos construtos, com o objetivo de representar a potencialização da evolução das competências em cada construto.

Analisando os resultados com base nos construtos definidos e em relação aos aspectos do contexto organizacional, nota-se que durante os ciclos a implantação da ABP na empresa teve o comprometimento da alta direção, pois, durante o ciclo 1, esta forneceu documentos como organograma da empresa e as etapas do sistema de planejamento. No ciclo 2, além de fornecer documentos, a alta direção respondeu ao questionário para identificação das atribuições dos engenheiros residentes em tempo hábil e participou do seminário de encerramento do ciclo; nos ciclos 3 e 4 a alta direção apenas participou do encerramento dos ciclos, logo o comprometimento da alta direção foi estimulado e desenvolvido durante o estudo exploratório. Com relação à facilidade de aceitação e incorporação da dinâmica de implantação da ABP pelo grupo, nota-se que apenas no ciclo 2 houve melhora, pois, a pedido do grupo ao final do primeiro ciclo, foram esclarecidas todas as dúvidas do programa, como os objetivos e metas a serem alcançados, o que justifica uma melhor aceitação do grupo no ciclo 2 ; no decorrer dos ciclos 3 e 4 observou-se a estagnação da aceitação e certo desinteresse pelo programa, conforme mostra a Figura 5.

De acordo com os construtos definidos para análise da aprendizagem individual e conforme a Figura 6, conclui-se que a competência de resolução de problemas foi estimulada durante todo o desenvolvimento dos ciclos. A competência de comunicação foi desenvolvida durante três dos quatro ciclos trabalhados. A condução de reuniões não foi desenvolvida, pois os membros do grupo não assumiram papel de coordenadores das reuniões. Vale ressaltar a mudança de comportamento percebida nos ciclos 1,2 e 3 , e a evolução da análise crítica de forma objetiva. 
Figura 5 - Gráfico do contexto organizacional

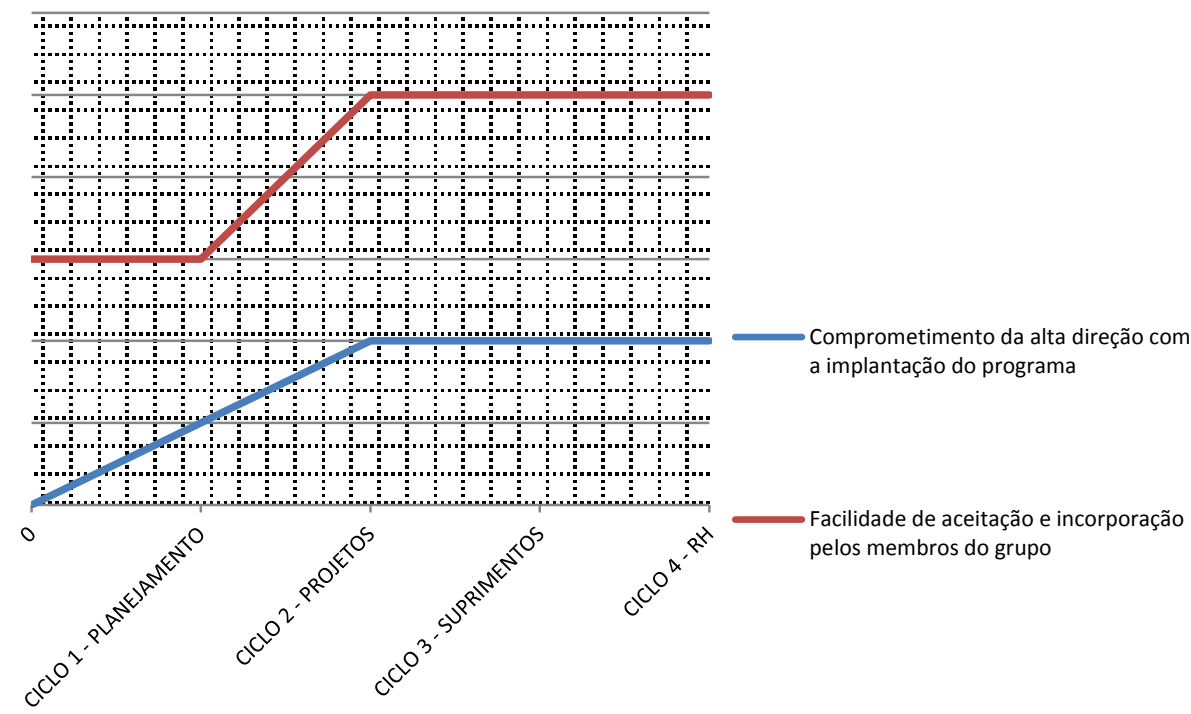

Figura 6 - Gráfico da aprendizagem individual

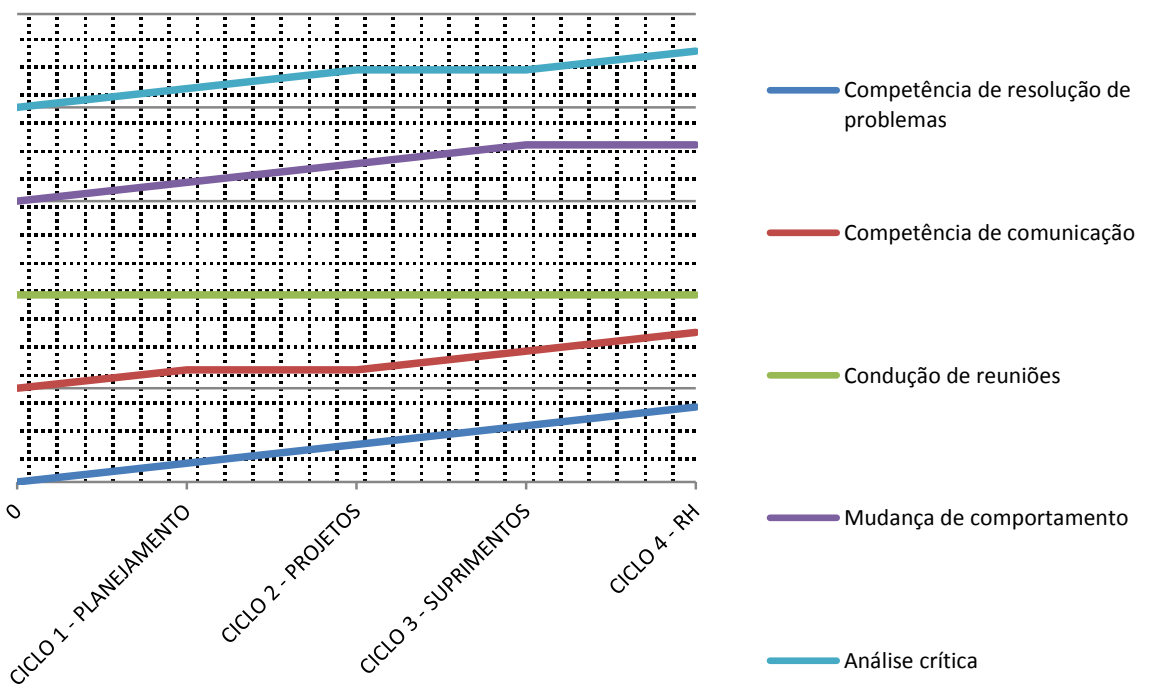

A Figura 7 mostra o desenvolvimento dos construtos definidos para a análise da aprendizagem coletiva durante os ciclos. Percebese que a troca de experiência cresceu ao longo de todo o desenvolvimento dos ciclos. A competência de mudança de regra foi estimulada durante os dois primeiros ciclos, porém sofreu um retrocesso no ciclo 3 e foi novamente desenvolvida no último ciclo. O desenvolvimento da competência de trabalho em equipe foi percebido apenas no ciclo 3 , e o desenvolvimento da tomada de decisão consensual pôde ser notado durante os ciclos 1 e 3 . $\mathrm{O}$ gerenciamento de conflito foi desenvolvido durante todos os ciclos, e vale destacar também o crescimento da liderança de grupo nos dois últimos ciclos.

Analisando o desenvolvimento das competências relacionadas à aprendizagem organizacional, conclui-se que dois dos três construtos definidos foram desenvolvidos. Não foi notório o desenvolvimento do trabalho em equipe, porém a disseminação das informações entre os demais setores da empresa foi feita através dos seminários de encerramento nos ciclos 2,3 e 4 . Tais informações foram repassadas para a alta direção e para a gerente do setor de Recursos Humanos por 
um engenheiro residente representante do grupo. Um melhor desempenho no processo foi desenvolvido somente no ciclo 3 , conforme mostra a Figura 8.

Foi estimulado o desenvolvimento das competências relacionadas aos aspectos do sistema de gestão da empresa. A ideia e a importância do pensamento sistêmico foram trabalhadas $\mathrm{e}$ comentadas pelos membros do grupo durante os ciclos 2 e 3. A criação de uma memória organizacional e a capacitação para a melhor utilização do sistema de planejamento da empresa foram enaltecidos e estimulados somente no ciclo inicial. A Figura 9 representa o desenvolvimento dos construtos relacionados aos aspectos do sistema de gestão da empresa.

\section{Figura 7 - Gráfico da aprendizagem coletiva}

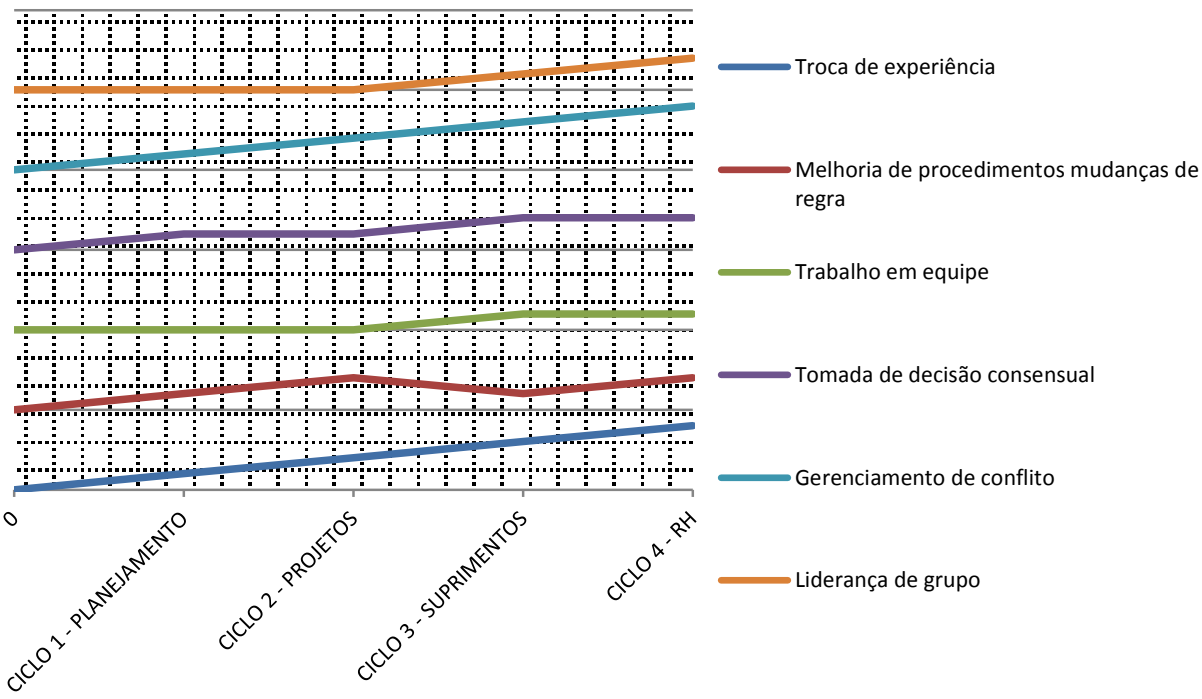

Figura 8 - Gráfico da aprendizagem organizacional

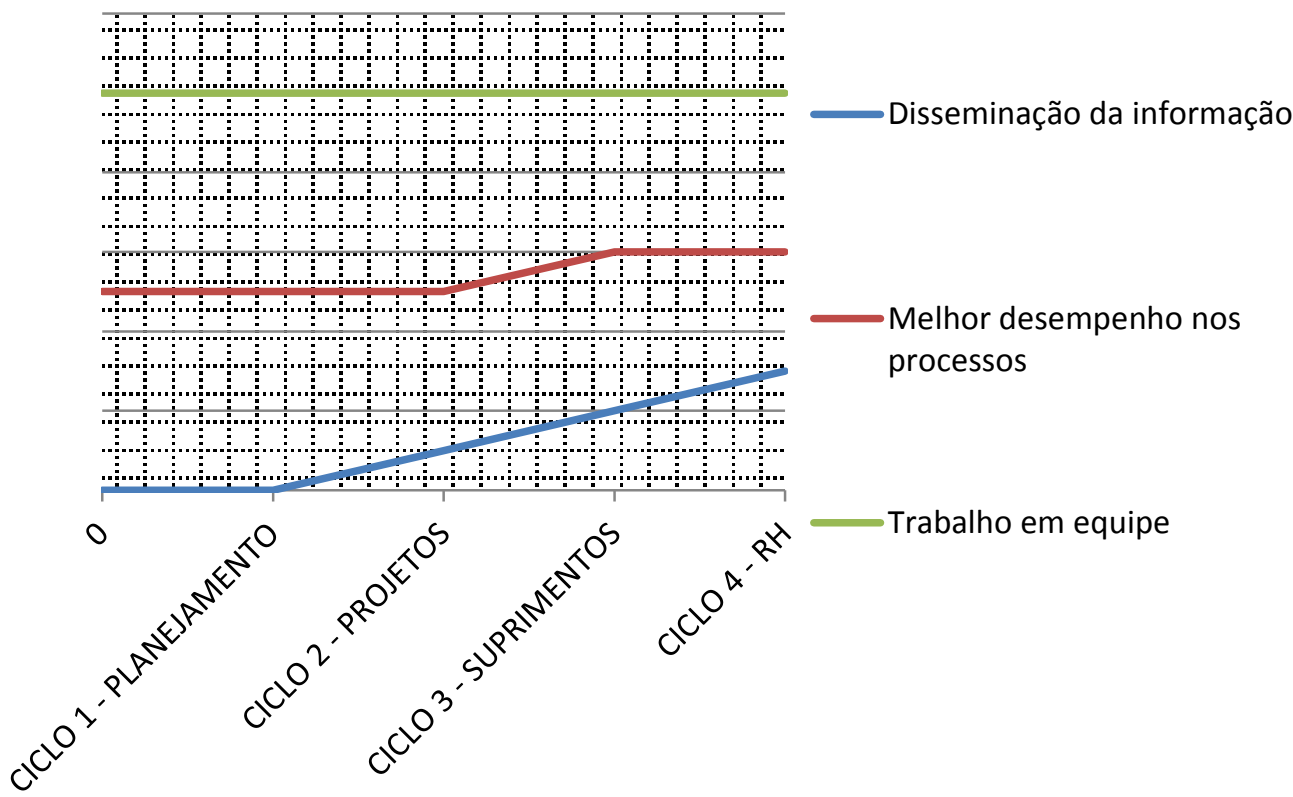

172 Martins, V. W. B; Neves, R. M. das; Macêdo, A. N. 
Figura 9 - Gráfico sistema de gestão

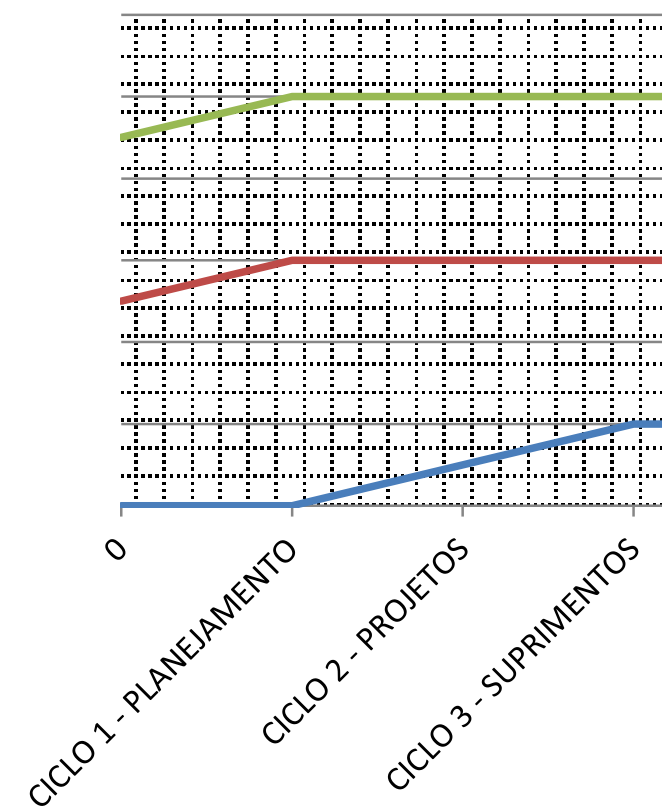

Pensamento sistêmico
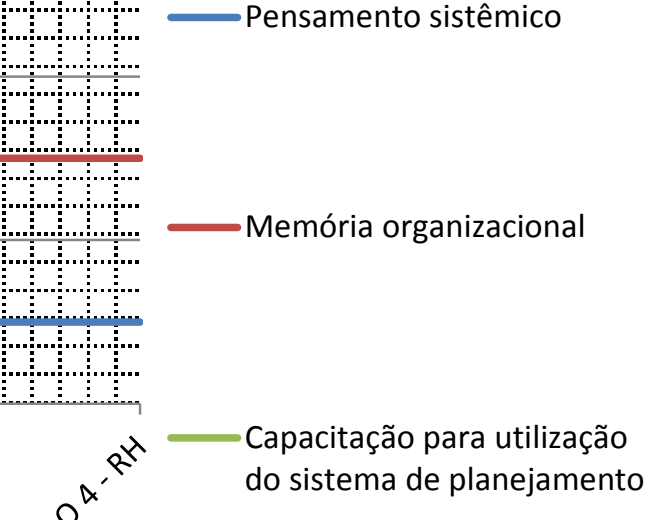

\section{Conclusões}

Observou-se que as competências técnicas passaram a assumir na prática uma posição secundária em relação às funções de gestão da obra, que vão desde o controle financeiro do suprimento de materiais, passando pela mobilização e desmobilização da mão de obra e pelo acompanhamento da liberação de recursos com o agente financeiro, reforçando o papel do engenheiro gestor de obras de não planejador, centralizando o controle e a busca de resultados no curto prazo.

O grupo teve dificuldades de ação em relação aos problemas gerenciais. Os problemas estavam sempre nos outros setores da empresa. Os gerentes tiveram dificuldades de quebrar a resistência em assumir as responsabilidades sobre os problemas apresentados (medo de exporem suas fraquezas), o que prejudicou a tomada de ação e consequentemente comprometeu o processo de desenvolvimento de competências gerenciais e o processo de aprendizagens do grupo. Eles tiveram dificuldades de desenvolver o autoconhecimento, refletir sobre suas ações e experiências.

Analisando os resultados da pesquisa e os aspectos organizacionais da empresa, foi identificado que as atividades gerenciais estão sendo impactadas, pois os gerentes devem se preocupar com o processo da solução dos problemas, e não com o resultado. Necessitam ver o problema como fazendo parte da solução. Observa-se que a ABP potencializou as competências referentes ao trabalho em equipe, liderança de grupo, comunicação, resolução de problemas, gerenciamento de conflitos, disseminação da informação e pensamento sistêmico.

A empresa precisa criar um ambiente propício à troca de informações entre seus setores, objetivando o engajamento das pessoas envolvidas em seu processo. É necessário certificar-se de que as pessoas sabem o propósito de seu trabalho e como ele contribui para que a organização alcance seus objetivos. Reconhecer e apreciar o trabalho desenvolvido pelos colaboradores também é válido. Vale ressaltar que feedbacks claros proporcionam o desenvolvimento de um bom trabalho, mas para isso as pessoas precisam de informações claras e em tempo hábil. É necessário não apenas avaliar o comportamento ou os resultados, mas também fazer com que as pessoas percebam sua importância para o sucesso da organização.

Foram identificados alguns problemas organizacionais que dificultavam as atividades gerenciais, tais como uma falta de padronização nos processos de gestão, falha no sistema de informação (obra x RH x suprimentos), falta de uma memória organizacional e falta de uma política organizacional mais clara, o que dificulta a tomada de decisão dos engenheiros de obra de acordo com os objetivos organizacionais.

Em relação ao modelo, é importante ressaltar que o problema trabalhado deve estar alinhado aos objetivos da organização e aos interesses do grupo (coletivo); de preferência real e que esteja ocorrendo no momento (vinculado ao dia a dia); 
relacionado com os processos gerenciais; relevante para a prática profissional. Ainda, a decisão do curso de ações a serem tomadas para sua resolução e implementação deve ser de responsabilidade do gerente de produção; e levar em consideração os aspectos humanos, sociais e técnicos. Isso faz com que o problema estimule a aprendizagem tanto individual quanto grupal e organizacional. É preciso que os membros do grupo entendam a necessidade das mudanças e das melhorias.

A otimização no sistema de informação entre setores (pensamento sistêmico), a criação de uma memória organizacional e a capacitação dos engenheiros de obra para melhor utilizar o sistema de planejamento caracterizam melhorias importantes e prioritárias para a empresa.

Ao longo do desenvolvimento da pesquisa, foram identificadas lacunas e oportunidades para a realização de novos estudos:

(a) implantar o programa em outras empresas construtoras, para que seja refinada a análise dos resultados e, ao mesmo tempo, para que se identifiquem barreiras na implantação dele;

(b) pesquisar até que ponto as características de ordem cultural podem interferir no processo de implantação da ABP; e

(c) investigar como quebrar ou minimizar a resistência dos gestores em assumir as responsabilidades sobre os problemas existentes nas obras.

\section{Referências}

BARROWS, H. S.; TAMBLYN, R. An Evaluation of Problem-Based Learning in Small Groups Using a Simulated Patient. Journal of Medical Education, v. 51, p. 52-54, 1976.

BOMFIM, R. Competência Profissional: uma revisão bibliográfica. Revista Organização Sistêmica, v. 1, n. 1, 2012.

BOTERF, G. L. Compétence et Navigation Professionnelle. Paris: Les Editions d'Organisation, 1999.

CHIAVEnato, I. Gestão de Pessoas. 3. ed. Rio de Janeiro: Campus, 2009.

COGHLAN, D.; BRANNICK, T. Doing Action Research in Your Own Organization. $2^{\text {nd. }} \mathrm{ed.}$ London: Sage, 2008.

DIAS, G. B. et al. Revisando a Noção de Competência na Produção Científica em Administração: avanços e limites. In: DUTRA, J. S.; FLEURY, M. T. L.; RUAS, R. Competências: conceitos, métodos e experiências. São Paulo: Atlas, 2008.
DUTRA, J. S. Gestão de Pessoas Com Base em Competências. In: DUTRA, J. S. (Org). Gestão por Competências: um modelo avançado para o gerenciamento de pessoas. São Paulo: Gente, 2001.

ENGEL, C. E. Not Just a Method But a Way of Learning. In: BOUD, D.; FELETTI, G. I. The Challenge of Problem-Based Learning. London: Kogan Page, 1997.

FISCHER, A. L. et al. Absorção do Conceito de Competência em Gestão de Pessoas: a percepção dos profissionais e as orientações adotadas pelas empresas. In: DUTRA, J. S.; FLEURY, M. T. L.; RUAS, R. Competências: conceitos, métodos e experiências. São Paulo: Atlas, 2008.

FURQUIM, V. D. O Papel das Competências Organizacionais na Formulação da Estratégia de Gestão de Pessoas em um Empreendimento Cooperativo. Porto Alegre, 2011. Dissertação (Mestrado em Administração) - Programa de PósGraduação em Administração, Universidade Federal do Rio Grande do Sul, Porto Alegre, 2011.

KALATZIS, A. C. Aprendizagem Baseada em Problemas em Uma Plataforma de Ensino a Distância Com o Apoio dos Estilos de Aprendizagem: uma análise do aproveitamento dos estudantes de engenharia. São Carlos, 2008. Dissertação (Mestrado em Engenharia de Produção) - Escola de Engenharia, Universidade Federal de São Carlos, São Carlos, 2008.

LEITE, I; GODOY, A; ANTONELLO, C. O Aprendizado da Função Gerencial: os gerentes como atores e autores do seu processo de desenvolvimento. Aletheia, São Paulo, n. 23, p. 27-41, jan./jun. 2006.

LERIPIO, A.; CRISTO, R. Perfil do Engenheiro Civil. Corporativo, 6 de janeiro, 2012.

MAMEDE, S. et al. Aprendizagem Baseada em Problemas: anatomia de uma nova abordagem organizacional. Fortaleza: Hucitec, 2001.

NEVES, R. M. Desenvolvimento de Competências de Gerentes Intermediários Através da Adaptação da Aprendizagem Baseada em Problemas - ABP. Porto Alegre, 2006. Tese (Doutorado em Engenharia Civil) Programa de Pós-Graduação em Engenharia Civil, Universidade Federal do Rio Grande do Sul, Porto Alegre, 2006.

PARRY, S. B. The Quest For Competencies. Training, v. 33, n. 7, p. 48-54, jul. 1998.

RUAS, R. L.; ANTONELLO, C. S.; BOFF, L. H. (Orgs.). Os Novos Horizontes da Gestão: aprendizagem organizacional e competências. Porto Alegre: Bookman, 2005.

174 Martins, V. W. B; Neves, R. M. das; Macêdo, A. N. 
SCHMIDT, H. G. Foundations of Problem-Based Learning: some explanatory notes. Medical Education, v. 27, n. 5, p. 422-432, 1993.

SILVA, E.; MENEZES E. Metodologia da Pesquisa e Elaboração de Dissertação. 4. ed. Florianópolis: Ed. da UFSC, 2005.

THIOLlENT, M. Metodologia da PesquisaAção. 15. ed. São Paulo: Cortez, 2007.
WOODS, D. R. Problem-Based Learning: how to gain the most from ABP. Hamilton, Canada: Griffin Printing, 1996.

\section{Agradecimentos}

À Coordenação de Aperfeiçoamento de Pessoal de Nível Superior - Capes, pelo apoio financeiro.

Renato Martins das Neves

Departamento de Engenharia Civil, Centro Tecnológico | Universidade Federal do Pará | Tel.: (91) 3201-7917 | Email: neves@ufpa.br

Alcebíades Negrão Macêdo

Instituto de Tecnologia | Universidade Federal do Pará | Rua Augusto Correa, 1, Guamá | Belém - PA - Brasil | CEP $66075-110$ | Tel.: (91) 3201-7905 | Email: anmacedo@ufpa.br

Revista Ambiente Construído

Associação Nacional de Tecnologia do Ambiente Construído

Av. Osvaldo Aranha, $99-3^{\circ}$ andar, Centro

Porto Alegre - RS - Brasil

CEP 90035-190

Telefone: +55 (51) 3308-4084

Fax: +55 (51) 3308-4054

www.seer.ufrgs.br/ambienteconstruido

E-mail: ambienteconstruido@ufrgs.br 